\title{
BIOMASS AND ENERGY YIELD OF LEGUMINOUS TREES CULTIVATED IN AMAZONAS
}

\author{
Karen Cristina Pires da Costa ${ }^{1}$, Roberval Monteiro Bezerra de Lima ${ }^{2}$, Marciel José Ferreira ${ }^{3 *}$ \\ ${ }^{1}$ Instituto Nacional de Pesquisas da Amazônia, Manaus, Amazonas, Brasil - karencosta15@gmail.com \\ ${ }^{2}$ Empresa Brasileira de Pesquisa Agropecuária Amazônia Ocidental, Manaus, Amazonas, Brasil - roberval.lima@embrapa.br \\ ${ }^{3 *}$ Universidade Federal do Amazonas, Manaus, Amazonas, Brasil - mjf.ufam@gmail.com
}

Received for publication: 06/06/2015 - Accepted for publication: 29/07/2015

\begin{abstract}
Energy forests emerge as an alternative to fossil fuels for energy production. The good performance of these forests should consider the selection of fast-growing species, high biomass productivity and energy yield. The aim was to investigate growth and energy yield of Acacia auriculiformis and Acacia mangium in a short-rotation plantation in the Amazonas. The energy yield was determined on 12 trees per species, from the results of biomass, calorific value and basic density. When 9 years-old, A. mangium had the highest growth rates in height $\left(1.9 \mathrm{~m} \mathrm{yr}^{-1}\right)$ and DBH $\left(2.5 \mathrm{~cm} \mathrm{yr}^{-1}\right)$. The greatest biomass productivity was observed in A. mangium (33.4 $\mathrm{Mg} \mathrm{ha}^{-1} \mathrm{yr}^{-1}$ ), which was $84 \%$ higher than $A$. auriculiformis (18.1 Mg ha $\left.\mathrm{yr}^{-1}\right)$. Basic density $\left(0.54 \mathrm{~g} \mathrm{~cm}^{-3}\right)$ and calorific value $\left(4,400 \mathrm{kcal} \mathrm{kg}^{-1}\right)$ showed no significant differences between species. The energy yield of $A$. mangium $\left(1,317 \mathrm{Gcal} \mathrm{ha}^{-1}\right)$ was twice as of A. auriculiformis ( $\left.684 \mathrm{Gcal} \mathrm{ha}^{-1}\right)$. A. mangium has better energy performance, compared to the A. auriculiformis, and therefore could the most recommended for the formation of energy forests in disturbed areas in the state of Amazonas.

Keywords: Acacia mangium; Acacia auriculiformis; short-rotation plantation.
\end{abstract}

\section{Resumo}

Biomassa e produtividade energética de leguminosas arbóreas cultivadas no Amazonas. As florestas energéticas representam alternativa à dependência do uso de combustíveis fósseis para a produção de energia. $\mathrm{O}$ bom desempenho dessas florestas deve considerar a seleção de espécies de rápido crescimento, alta produtividade em biomassa e rendimento energético. $\mathrm{O}$ objetivo foi investigar o crescimento e a produtividade energética de Acacia auriculiformis e Acacia mangium em plantios florestais de curta rotação no Amazonas. A produtividade energética foi determinada em 12 árvores de cada espécie, a partir dos resultados de biomassa, poder calorífico e densidade básica. Aos 9 anos, A. mangium teve as maiores taxas de crescimento em altura $\left(1,9 \mathrm{~m} \mathrm{ano}^{-1}\right)$ e DAP $\left(2,5 \mathrm{~cm} \mathrm{ano}^{-1}\right)$. A maior produtividade de biomassa foi observada em A. mangium $\left(33,4 \mathrm{Mg} \mathrm{ha}^{-1}\right.$ ano $^{-1}$ ), que foi $84 \%$ superior a de A. auriculiformis $\left(18,1 \mathrm{Mg} \mathrm{ha}^{-1} \mathrm{ano}^{-1}\right)$. A densidade básica $\left(0,54 \mathrm{~g} \mathrm{~cm}^{-3}\right)$ e o poder calorífico (4.400 kcal kg-1) não apresentaram diferenças significativas entre as espécies. A produtividade energética de A. mangium $\left(1.317 \mathrm{Gcal} \mathrm{ha}^{-1}\right)$ foi duas vezes maior que a de $A$. auriculiformis $\left(684 \mathrm{Gcal} \mathrm{ha}^{-1}\right)$. Acacia mangium tem melhor desempenho energético quando comparada à A. auriculiformis, sendo portanto mais recomendada para a formação de florestas energéticas em áreas alteradas no estado do Amazonas.

Palavras-chave: Acacia mangium; Acacia auriculiformis; plantios de curta rotação.

\section{INTRODUCTION}

World's uncertainty regarding future energy availability results from political instabilities, increase of oil price, climate changes and, mainly, from the constant threat of traditional fossil fuel sources running out (HOUTAR, 2010). As consequence, several countries are investing in new renewable energy sources, like energy forests (PÉREZ et al., 2014). However, these natural sources still represent a very small part of the global energy demand.

The global carbon dioxide emission $\left(\mathrm{CO}_{2}\right)$ will reach values of $40 \mathrm{Gt}$ in 2030 (AGÊNCIA INTERNACIONAL DE ENERGIA (IEA), 2006). Between 1750 and 2011, emission of $\mathrm{CO}_{2}$ caused by

FLORESTA, Curitiba, PR, v. 45, n. 4, p. 705 - 712 , out. / dez. 2015.

Costa, K. C. P. da. et al.

ISSN eletrônico 1982-4688 / ISSN impresso 0015-3826 
fossil fuels burning and production of concrete represented $67 \%$ of the total emissions (PAINEL INTERGOVERNAMENTAL SOBRE MUDANÇAS CLIMÁTICAS (IPCC), 2014). Incentives to energy forests as source of energy could positively modify this scenario, because it is estimated that the process of energy production from wood results in $60 \%$ less $\mathrm{CO}_{2}$ emissions in the atmosphere than the emissions generated by the use of fossil fuels (HOUTAR, 2010).

Plantation of energy forests could also contribute to reduction of deforestation rates. Until 2012, deforested area in the group of states known as Legal Amazonas was about $753.000 \mathrm{~km}^{2}$, where the Amazonas state itself contributes with $5 \%$ of this amount (INSTITUTO NACIONAL DE PESQUISAS ESPACIAIS (INPE), 2014). The municipalities of Itacoatiara, Manicoré and Maués, which occupy $4^{\text {th }}, 5^{\text {th }}$ and $6^{\text {th }}$ place in the deforestation ranking of the Amazonas state, are between the municipalities that had the greatest production of wood in 2012 (INSTITUTO BRASILEIRO DE GEOGRAFIA E ESTATÍSTICA (IBGE), 2013; INPE, 2014).

Selection of exotic species for plantations in the Amazonas must be considered when the intention is to reintroduce deforested areas into productive processes, with the intent to reduce the exploitation pressure on native forests. These species, in general, are tolerant to different environmental conditions, like low quality locations in terms of nutrients availability and soil compaction, like for example pasture areas, which represent around 66\% of the deforested area of the Legal Amazonas (INPE, 2014).

Potential of energy forests partly depends on productivity of the woody biomass of planted species, from characteristics of wood, mainly in terms of density and calorific power, from adaptation skills of the species to the different conditions in the location and from the silvicultural methods applied. Expectation is for the species to accumulate more biomass in a short period, with high density and high calorific power of the produced wood (PÉREZ et al., 2014).

The species A. auriculiformis A. Cunn. ex Benth. and A. mangium Willd may be adequate to formation of energy forests, because of their rapid growth rate and high wood biomass production (BARROS et al., 2009; KRISNAWATI et al., 2011). However, the best understanding of these species performance in terms of energy production in the Amazonas climate and soil conditions still need improvement. In this context, the present study aimed to answer three principal questions: i) Are there differences in terms of energy production between the species A. auriculiformis and A. mangium? ii) If such differences exist, which characteristics most contribute to them? and iii) Which of the species would be the more indicated to plant energy forests in the Amazon region? Thus, aim of the present work was to investigate growth and energy productivity of Acacia auriculiformis and Acacia mangium in shortrotation forest plantations in the Amazonas state.

\section{MATERIAL AND METHODS}

\section{Location and characterization of the experiment}

The studied plantations are located between coordinates $03^{\circ} 14^{\prime} \mathrm{S}$ and $60^{\circ} 13^{\prime} \mathrm{W}$. This area belongs to Embrapa Amazônia Ocidental, located in the Experimental Land of Caldeirão, Iranduba, AM. Annual average temperatures and rainfall, in the period from 1971 and 2008 were, respectively, $25.9{ }^{\circ} \mathrm{C}$ and 2,619 mm (ANTÔNIO, 2008) and climate, according to Köppen classification, is Afi type. Soil of the region belongs to the class of Yellow Latosols (ABREU et al., 2012).

Plantations of A. auriculiformis and A. mangium were made between November 2002 and February 2003. To do that, seven years old plantlets, with an average height of $30 \mathrm{~cm}$ produced in the nursery of Embrapa Amazônia Ocidental. Overall, 200 plantlets were planted per each species in 0.12 hectares plots $(30 \mathrm{x} 40 \mathrm{~m})$. Spacing was $3.0 \times 2.0 \mathrm{~m}$. Plantlets were fertilized with triple superphosphate, only at the moment of plantation. After 30 days, plantlets went through replanting, and grass competition was controlled yearly.

\section{Sampling}

With the intention to define the number of trees to be sampled, DBH diameters of all trees where measured ( $\mathrm{DBH}$, measured at 1.30 meters from the ground), thus conducting a pilot inventory. Every single tree was considered as sample unit. Later, each plantation was divided into three DBH classes, lower $(4.8-10.6 \mathrm{~cm})$, middle $(10.6-16.4 \mathrm{~cm})$ and upper $(16.4-22.2 \mathrm{~cm})$ for A. auriculiformis and lower $(6.2-17.2 \mathrm{~cm})$, middle $(17.2-28.2 \mathrm{~cm})$ and upper $(28.2-39.2 \mathrm{~cm})$ for A. mangium. In each class, four trees were chopped, totalizing 12 trees from each species. 


\section{Growth in height and diameter}

Growth variables considered were total height and DBH of the 24 selected trees. Height was measured after logging and values were obtained by a metric measuring tape with $1.0 \mathrm{~cm}$ resolution. DBH was measured by a diametric measuring tape, with $0.1 \mathrm{~cm}$ resolution. The average annual increment (AAI) in height and diameter was calculated for a period of 9 years.

\section{Biomass}

Alive biomass above the ground was quantified by a destructive method. Biomass components of trees were divided into leaves, thin branches $(\varnothing<10 \mathrm{~cm})$, thick branches $(\varnothing \geqslant 10 \mathrm{~cm})$ and stem. Material extracted from leaves and thin branches was, respectively, 3.0 and $5.0 \mathrm{~kg}$ of biomass, while thick branches and stem gave discs $5.0 \mathrm{~cm}$ thick, cut at $0 \%$ (base), 50\% and 100\% (top). Fresh biomass of each section was measured in field using a weighting scale type Micheletti MIC-2 with maximum load of 300 $\mathrm{kg}$ and a precision of $200 \mathrm{~g}$, calibrated before use with sampling weights. To determine dry biomass, materials were put in a forced ventilation oven with controlled temperature at $100-105^{\circ} \mathrm{C}$ until mass was stable. Next, samples were weighted with a digital scale with $30 \mathrm{~kg}$ maximum load and precision of $1.0 \mathrm{~g}$. Basing on fresh biomass data of the aliquots, for each component of the logged trees, dry biomass was calculated with the following equation (TÉO, 2009):

$$
B s_{\text {total }}=B f_{\text {total }} \times\left(\frac{B s_{\text {aliquot }}}{B f_{\text {aliquot }}}\right)
$$

where $: \mathrm{B}_{\mathrm{s}}(\mathrm{kg})=$ Dry biomass, $\mathrm{B}_{\mathrm{f}}(\mathrm{kg})=$ Fresh biomass.

\section{Determination of calorific power and basic density}

From the 24-logged trees, $5.0 \mathrm{~cm}$ thick discs were extracted to study the calorific power. These discs were taken from DBH height. Discs were wrapped in paper bags and taken to the Laboratory of Forest Products belonging to Embrapa Amazônia Ocidental. Next, from each disc, three cubes were extracted in the sapwood-to-core direction, weighting $0.5 \mathrm{~g}$, as recommended by the calorimeter's manual. These cubes allowed determination of the superior calorific power, using a calorimetric pump Alemmar type Cal $2 k$.

To study basic density, $5.0 \mathrm{~cm}$ thick discs along the stem were collected, sectioned at $0 \%$ (base), $50 \%$ and $100 \%$ (top). Disks were wrapped in paper bags and taken to the Laboratory of Forest Products belonging to Embrapa Amazônia Ocidental. In this laboratory, two wedges were cut from the opposite sides of each disk. Next, basic density of bark and wood components was determined basing on NBR 11.941 (ASSOCIAÇÃO BRASILEIRA DE NORMAS TÉCNICAS (ABNT), 2003).

\section{Estimation of energy production and energy yield}

Estimations of energy production and energy yield of A. auriculiformis and A. mangium were calculated basing on the following equations (CINTRA, 2009):

$$
\begin{gathered}
P E=(B s \times P C S) / 10^{6} \\
P d E=P E \times N^{\circ} \text { of trees } h a^{-1}
\end{gathered}
$$

where: PE $(\mathrm{Gcal})=$ Energy production; PdE $\left(\mathrm{Gcal}_{\mathrm{ha}}{ }^{-1}\right)=$ Energy Yield; Bs $(\mathrm{kg})=$ dry biomass; PCS $\left(\mathrm{kcal} \mathrm{kg}^{-1}\right)=$ Superior calorific power.

\section{Experimental design and statistical analyses}

Experimental design was completely randomized (CRD), with 2 treatments and 12 replications. Data were submitted to Shaphiro-Wilk and Bartlett's tests to verify respectively normality and homogeneity of variances. Next, data were submitted to analysis of variance (Anova One Way), and all the statistical analyses were performed using the program $\mathrm{R}$ (version 2.15.1). 


\section{RESULTS AND DISCUSSION}

\section{Height and diameter growth}

Acacia mangium, when 9 years old, presented the greatest DBH and height growths. This species reached an average DBH value 1.6 times bigger than A. auriculiformis $(p<0.05$; Table 1$)$. The height and DBH average annual increments (AAI) of A. mangium were, on average, $33 \%$ higher than results obtained by A. auriculiformis (Table 1)

Table 1. Growth of Acacia auriculiformis and Acacia mangium in 9-years-old plantation in Iranduba, AM. Mean \pm Mean standard error $(\mathrm{n}=12)$.

Tabela 1. Biometria de Acacia auriculiformis e Acacia mangium em plantio de 9 anos em Iranduba, AM. Média \pm Erro padrão da média $(\mathrm{n}=12)$.

\begin{tabular}{|c|c|c|c|c|}
\hline \multirow[b]{2}{*}{ Species } & \multirow[b]{2}{*}{$\begin{array}{l}\text { Total height } \\
\text { (m) }\end{array}$} & \multirow[b]{2}{*}{$\begin{array}{l}\text { DBH } \\
(\mathbf{c m})\end{array}$} & \multicolumn{2}{|c|}{ AAI } \\
\hline & & & $\begin{array}{c}\text { Total height } \\
\left(\mathrm{m} \text { ano }^{-1}\right)\end{array}$ & $\begin{array}{c}\text { DBH } \\
\left(\mathrm{cm} \mathrm{ano}^{-1}\right) \\
\end{array}$ \\
\hline A. auriculiformis & $14.9 \mathrm{~b} \pm 3.4$ & $14.7 \mathrm{~b} \pm 4.0$ & $1.7 \mathrm{a} \pm 0.3$ & $1.6 b \pm 0.3$ \\
\hline A. mangium & $17.3 \mathrm{a} \pm 2.1$ & $22.8 \mathrm{a} \pm 6.5$ & $1.9 \mathrm{a} \pm 0.2$ & $2.5 \mathrm{a} \pm 0.5$ \\
\hline
\end{tabular}

Means followed by the same letters in columns are not statistically different (Anova One Way, $p>0,05$ ).

AAI of nine Amazon native species, considered of rapid growth (Bertholletia excelsa Bonpl., Carapa guianensis Aubl., Cedrela odorata L., Copaifera multijuga Hayne, Dipteryx odorata (Aubl.) Willd., Hymenaea courbaril L., Sclerolobium paniculatum Vogel., Swietenia macrophylla King and Trattinickia burseraefolia (Mart.) Willd.), planted in similar environmental conditions of this study, when 11 years old, varied from $0.8 \mathrm{~cm}_{\text {year }}{ }^{-1}$ to $2.0 \mathrm{~cm} \mathrm{year}^{-1}$ in DBH. Total height varied from $0.9 \mathrm{~m}$ year ${ }^{-1}$ to $1.5 \mathrm{~m}$ year $^{-1}$ (SOUZA et al., 2008). Comparing these results with the present work, one can observe that AAI of A. mangium in DBH and height was bigger than of the nine species, while A. auriculiformis had growth only smaller than of Sclerolobium paniculatum Vogel.

This way, despite the difference between A. mangium and A. auriculiformis height and DBH results, both species proved to be adequate to plantations in the Amazonas climate and soil, since they presented significantly bigger growth rates compared to some native species indicated to formation of energy forests in this region. Forest tree species recommended for creation of energy production plantations must have, besides other characteristics (e.g. growth rate in monocultures, easy propagation, resistance to pests and diseases), a great growth potential. For species in field, growth potential is related to their efficiency in capture and use of primary resources like water, $\mathrm{CO}_{2}$, light and nutrients, and this efficiency is peculiar to every single species (SANTOS JR. et al., 2006). For this reason, one can observe different growth rates between different trees, even if they belong to the same genus.

\section{Biomass}

The biggest biomass stocks, considering all components, were observed in A. mangium ( $p<0.05$; Table 2), being these stocks 2 times bigger compared to A. auriculiformis. The biomass annual average increment of A. mangium was $84 \%$ bigger than of A. auriculiformis.

Table 2. Biomass in the tree components of Acacia auriculiformis and Acacia mangium from 9-yearsold plantations in Iranduba, AM. Mean \pm Mean standard error $(\mathrm{n}=12)$.

Tabela 2. Estoques de biomassa nos compartimentos arbóreos de Acacia auriculiformis e Acacia mangium em condição de plantio no município de Iranduba, AM. Média \pm Erro padrão da média $(\mathrm{n}=12)$.

\begin{tabular}{|c|c|c|c|c|c|}
\hline \multirow{2}{*}{ Species } & \multicolumn{4}{|c|}{ Biomass (Mg ha $\left.{ }^{-1}\right)$} & \multirow{2}{*}{$\begin{array}{c}\text { AAI } \\
\left(\mathrm{Mg} \mathrm{ha}^{-1} \text { year }^{-1}\right)\end{array}$} \\
\hline & Leaves & Thin Branches & Stems & Total & \\
\hline A. auriculiformis & $6.0 \mathrm{cB} \pm 0.7$ & $13.3 \mathrm{bB} \pm 1.6$ & $143.9 \mathrm{aB} \pm 13.9$ & $163.2 \mathrm{~B} \pm 14.8$ & $18.1 \mathrm{~B} \pm 1.6$ \\
\hline A. mangium & $14.2 \mathrm{cA} \pm 2.8$ & $37.6 \mathrm{bA} \pm 9.0$ & $249.1 \mathrm{aA} \pm 45.4$ & $301.0 \mathrm{~A} \pm 54.8$ & $33.4 \mathrm{~A} \pm 6.1$ \\
\hline
\end{tabular}

Means followed by the same lower case letters in lines and upper case in columns are not significantly different respectively between components and species (Anova One Way, $p>0,05$ ). 
Difference in biomass accumulation between these two species may be related to adapting strategies used by each of them, because besides environmental conditions, other factors may determine biomass accumulation in forest plantations, like for example genetic potential of the species. There are differences between species in terms of biomass production efficiency per unit of nutrient absorbed, and this fact may be related to phenotypic plasticity aimed to help the performance of some species in locations with low availability of resources (SANTOS JR. et al., 2006).

Comparing biomass stocks of A. auriculiformis and A. mangium in the present study, with data from other works (KUMAR et al., 1998; SIREGAR et al., 2008), one can verify that results obtained are within the range of variation presented in literature. However, biomass stock of A. auriculiformis in the present work, is similar to biomass stocks accumulated by this species in poor soils, which allows to infer that its biomass stock, in the conditions of soil and climate of the Amazonas, was low, the opposite of $A$. mangium.

Both species presented significant differences in biomass distribution between the different tree components. Leaves represented the smallest stocks, and stems gave the greatest stocks $(p<0.05$; Figure 1). Biomass of leaves was on average 20 times smaller than stem biomass, twice bigger than thin branch biomass and none of the species presented thick branches (Figure 1).

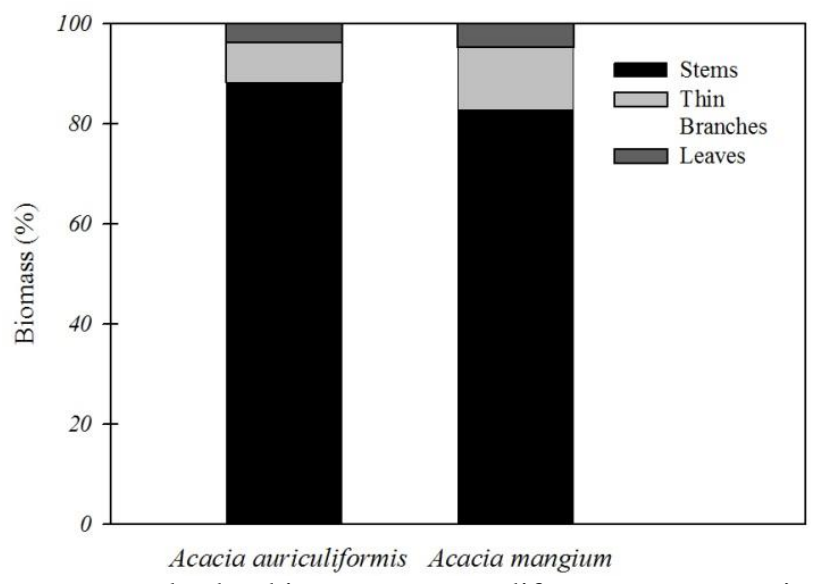

Figura 1. Distribuição percentual de biomassa nos diferentes compartimentos arbóreos de $A$. auriculiformis e A. mangium, aos 9 anos, em plantio em Iranduba, AM.

Figure 1. Distribution of percentages of biomass in different components of the A. auriculiformis and A. mangium of 9-years-old plantations in Iranduba, AM.

Distribution percentage of biomass in the different tree components of the two species was similar. In $A$.mangium, $83 \%$ of the total biomass was represented by stem, while $13 \%$ by thin branches and just $5 \%$ by leaves. Around $88 \%$ of the entire A. auriculiformis biomass was accumulated in stems, while $8 \%$ was in thin branches and $4 \%$ in leaves. Thus, the predominant biomass distribution order, in the different tree components of both species, was the following: stems $>$ thin branches > leaves (Figure 1).

Plantation of energy forests must consider biomass distribution strategy of the species, besides growth rates (PÉREZ et al., 2014). Forest species with greater investment in the woody components as biomass distribution strategy, especially in stems, are better to form energy forests, because this component presents lower water contents, lower ash content and higher density, improving their energetic performance (PÉREZ et al., 2014).

Biomass distribution between components of A. mangium and A. auriculiformis was similar to observations in other species. In Ceiba pentandra (L.) Gaertn., for example, when 6 years old, in environmental and spacing conditions similar to this study, biomass distribution order was: stem (78\%) > branches (17\%) > leaves (5\%) (NEVES et al., 2001). In Eucalyptus benthamii Maid and Camb., biomass distribution percentage, when 4 years old, planted in a 3.0 x $2.0 \mathrm{~m}$, was: stem $(74.9 \%)>$ branches $(15.2 \%)>$ leaves $(7.1 \%)$ (SILVA et al., 2004). 


\section{Calorific power and basic density}

Values of superior calorific power and basic density of wood and bark did not present significant differences between species ( $p>0.05$; Table 3$)$.

Table 3. Basic density and calorific power of Acacia auriculiformis and Acacia mangium of 9-years old plantations in Iranduba, AM. Mean \pm Mean standard error $(\mathrm{n}=12)$.

Tabela 3. Densidade básica e poder calorífico de Acacia auriculiformis e Acacia mangium, aos 9 anos, em condição de plantio no município de Iranduba, AM. Média \pm Erro padrão da média $(\mathrm{n}=12)$.

\begin{tabular}{lccc}
\hline \multirow{2}{*}{ Species } & \multicolumn{2}{c}{ Basic density $\left(\mathbf{g ~ c m}^{-\mathbf{3}}\right)$} & $\begin{array}{c}\text { Superior calorific } \\
\text { power }\left(\mathbf{k c a l ~} \mathbf{~ k g}^{-1}\right)\end{array}$ \\
\cline { 2 - 3 } & Bark & Wood & $4,400 \mathrm{a} \pm 81.2$ \\
A. auriculiformis & $0.48 \mathrm{a} \pm 0.13$ & $0.55 \mathrm{a} \pm 0.09$ & $4,377 \mathrm{a} \pm 79.7$ \\
A. mangium & $0.48 \mathrm{a} \pm 0.08$ & $0.54 \mathrm{a} \pm 0.07$ & \\
\hline
\end{tabular}

Means followed by the same letters in columns are not significantly different (Anova One Way, $p>0,05$ ).

Basic density values are similar to what described in literature, where one can find a variation of $0.50-0.60 \mathrm{~g} \mathrm{~cm}^{-3}$ for the species of genus Acacia, however, calorific power was smaller than results presented in other works, indicating a variation of 4,500 - 4,900 kcal kg-1 (BARROS et al., 2009; KRISNAWATI et al., 2011). Despite this, results obtained for basic density and superior calorific value where similar to the ones found in literature for species of the genus Eucalyptus, which in plantations for energy production in Minas Gerais was from 0.47 to $0.53 \mathrm{~g} \mathrm{~cm}^{-3}$ (SANTOS et al., 2012). In turn, calorific power observed in these same species was $4,456 \mathrm{kcal} \mathrm{kg}^{-1}$ (SANTOS et al., 2012).

Superior calorific power suffers little influence from the environment, because it is a characteristic more related to genetics of the species (SANTOS et al., 2012). One can verify this fact in some works analyzing superior calorific value of species of the genus Eucalyptus (SANTOS et al., 2012). However, age may have influence on this variable and it was observed that superior calorific value tends to decrease with trees ageing (VIDAURRE et al., 2012). Thus, age can be considered one of the principal responsible factors for the low calorific value observed in the present study when compared to literature.

Basic density reached by $A$. auriculiformis and A. mangium in the present study was approximately $10 \%$ bigger than basic density of some native species of the Amazonas with potential to form energy forests. The species Inga edulis Mart. and Tachigali chrysophylla (Poepp.) Zarucchi \& Herend., when 7 years old, planted in the same environmental conditions of the species analyzed in the present study, reached $0.52 \mathrm{~g} \mathrm{~cm}^{-3}$ and $0.48 \mathrm{~g} \mathrm{~cm}^{-3}$ (BARROS et al., 2012). Paricá, (Schizolobium amazonicum Huber ex Ducke), a species that was indicated for plantation of energy forests, when 9 years old, reached a basic density of $0.28 \mathrm{~g} \mathrm{~cm}^{-3}$ (VIDAURRE et al., 2012).

Calorific value observed in A. mangium and A. auriculiformis was bigger than other native species of the Amazonian biome too (SANTOS et al., 2013). Among the considered species there are Hura crepitan L. (3,989 kcal kg-1), Cassia leiandra Benth. (4,066 kcal kg-1), Cordia bicolor (Ducke) Chevalier. $\left(4,109 \mathrm{kcal} \mathrm{kg}^{-1}\right)$ Sacoglottis guianensis Benth. $\left(3,989 \mathrm{kcal} \mathrm{kg}^{-1}\right)$ and Planchonella pachycarpa Pires $\left(3,655 \mathrm{kcal} \mathrm{kg}^{-1}\right)$ (SANTOS et al., 2013).

\section{Estimate of energy production and energy yield}

Energy yield of A. mangium was about $84 \%$ bigger than energy yield of A. auriculiformis $(p<0.05$; Table 4).

Comparing values of energy production and energy yield of A. auriculiformis and A. mangium to other species, among others the ones belonging to the genus Eucalyptus, one can observe that the species analyzed in the present work present an high energy yield.

Energy yield of six Eucalyptus species, when 3 years old, varied from 662 to $1,259 \mathrm{Gcal} \mathrm{ha}^{-1}$ (MIGLIORINI et al., 1980). Energy production of nine Eucalyptus species, when 10 years old, varied from 0.3 to $2.5 \mathrm{Gcal}^{-1}$ tree ${ }^{-1}$ (BRITO et al., 1983).

Results observed in this work are within the range of variation verified in 12 species, in 6 to 12 years old plantations for production of energy in the region of São Paulo. The observed variation of energy production in these plantations was from 0.04 to $0.61 \mathrm{Gcal}^{-1} \mathrm{e}^{-1}$, while energy yield varied from 67 to $1,021 \mathrm{Gcal} \mathrm{ha}^{-1}$ and the average annual increment varied from 11 to $128 \mathrm{Gcal} \mathrm{ha}^{-1}$ year $^{-1}$ (CINTRA, 
2009). In the same work, Acacia polyphylla DC., when 8 years old, reached an energy production of 0,26 $\mathrm{Gcal}_{\text {tree }}^{-1}$ and an energy yield of $441 \mathrm{Gcal} \mathrm{ha}^{-1}$, with average annual increment of $55 \mathrm{Gcal} \mathrm{ha}^{-1}$ year $^{-1}$.

Table 4. Production, energy yield and average annual increment of energy yield of Acacia auriculiformis and Acacia mangium, of 9-years-old plantations in Iranduba, AM. Mean \pm Mean standard error $(\mathrm{n}=12)$.

Tabela 4. Produção, produtividade energética e incremento médio anual em produtividade energética de Acacia auriculiformis e Acacia mangium, aos 9 anos, em Iranduba, AM. Média \pm Erro padrão da média $(\mathrm{n}=12)$.

\begin{tabular}{lccc}
\hline Species & $\begin{array}{c}\text { Energy production } \\
\left(\text { Gcal tree }^{-\mathbf{1}}\right)\end{array}$ & $\begin{array}{c}\text { Energy yield } \\
\left(\mathbf{G c a l ~ h a}^{-\mathbf{1}}\right)\end{array}$ & $\begin{array}{c}\text { AAI of energy yield } \\
\left(\mathbf{G c a l ~ h a}^{-\mathbf{1}} \mathbf{y e a r}^{-\mathbf{1}}\right)\end{array}$ \\
\hline A. auriculiformis & $0.4 \mathrm{~b} \pm 0.1$ & $684 \mathrm{~b} \pm 153$ & $86 \mathrm{~b} \pm 16$ \\
A. mangium & $0.8 \mathrm{a} \pm 0.2$ & $1,317 \mathrm{a} \pm 232$ & $146 \mathrm{a} \pm 25$ \\
\hline Means followed by the same letters in columns are not significantly different (Anova One Way, $p>0.05)$.
\end{tabular}

\section{CONCLUSIONS}

- Considering Amazonian climate and soil conditions, both species Acacia mangium and Acacia auriculiformis have great energy production. However, A. mangium had twice the energetic performance of A. auriculiformis;

- Difference of energy yield between species was mainly influenced by the greater mass accumulation of A. mangium;

- A. mangium is more suitable to install energy forests in deforested areas of the Amazonas state.

\section{ACKNOWLEDGEMENTS}

To Embrapa Amazônia Ocidental and to Fundação de Amparo à Pesquisa of the Amazonas state (FAPEAM) for the logistic and financial support.

\section{REFERENCES}

ASSOCIAÇÃO BRASILEIRA DE NORMAS TÉCNICAS (ABNT). NBR 11.941: Madeira determinação da densidade básica. Rio de Janeiro, 2003. 6 p.

ABREU, N. R. P. de; SILVA, D. M.; CARVALHO. D. P.; SAMPAIO. F. P. R. Uma Abordagem geográfica dos aspectos físicos e dos potenciais econômicos do solo de Iranduba - AM. Geonorte, Manaus, v. 2, p. 659 - 667, 2012.

ANTÔNIO, I. C. Boletim Agrometeorológico 2008: Estação Agroclimatológica do Campo Experimental do km 29 da Rodovia AM 010, da Embrapa Amazônia Ocidental. Manaus: Embrapa Amazônia Ocidental, 2008. 28 p. (Documentos 77).

BARROS, S. V. dos S.; PIO, N. da S.; NASCIMENTO, C. C. do; COSTA, S. de S. Avaliação do potencial energético das espécies florestais Acacia auriculiformis e Ormosia paraensis cultivadas no município de Iranduba/Amazonas, Brasil. Madera y Bosques, Xalapa, v. 15, p. 59 - 69, 2009.

BARROS, S. V. dos S.; NASCIMENTO, C. C. do; AZEVEDO, C. P. de. Caracterização tecnológica da madeira de três espécies florestais cultivadas no Amazonas: alternativa para produção de lenha. Floresta, Curitiba, v. 42, p. 725 - 732, 2012.

BRITO, J. O.; BARRICHELO, L. E. G.; SEIXAS, F. Análise da produção energética e de carvão vegetal de espécies de eucalipto. IPEF, Piracicaba, v. 23, p. 53 - 56, 1983.

CINTRA, T. C. Avaliações energéticas de espécies florestais nativas plantadas na região do Médio Parapanema, SP. 84 f. Dissertação (Mestrado em Recursos Florestais, com opção em Tecnologia de Produtos Florestais) - Universidade de São Paulo/Escola Superior de Agricultura "Luiz de Queiroz", Piracicaba, 2009. 
HOUTAR, F. A Agroenergia: Solução para o clima ou saída da crise para o capital?. Petrópolis: Editora Vozes Ltda, 2010. 324 p.

INSTITUTO BRASILEIRO DE GEOGRAFIA E ESTATÍSTICA (IBGE). Produção da Extração Vegetal e da Silvicultura 2012. Rio de Janeiro: IBGE, 2013. 58 p.

AGÊNCIA INTERNACIONAL DE ENERGIA (IEA). World energy outlook 2006. Paris: International Energy Agency, 2006. 596 p.

PAINEL INTERGOVERNAMENTAL SOBRE MUDANÇAS CLIMÁTICAS (IPCC). Climate change 2013: the physical science basis - Summary for policymakers. Disponível em: $\langle$ http://www.ipcc.ch/report/ar5/wg1/docs/WGIAR5_SPM_brochure_en.pdf >. Acesso em: 15/01/2014.

INSTITUTO NACIONAL DE PESQUISAS ESPACIAIS (INPE). Programa de Monitoramento da Floresta Amazônica Brasileira por Satélite. Disponível em: <http://www.inpe.br>. Acesso em: 29/01/2014.

KRISNAWATI, H.; KALLIO, M.; KANNINEN, M. Acacia mangium Willd.: Ecology, silviculture and productivity. Bogor: CIFOR, 2011. 26 p.

KUMAR, B. M.; GEORGE, S. J.; JAMALUDHEEN, V.; SURESH, T. K. Comparison of biomass production, tree allometry and nutrient use efficiency of multipurpose trees grown in woodlot and silvopastoral experiments in Kerala, India. Forest Ecology and Management, Amsterdam, v. 112, p. 145 - 163, 1998.

MIGLIORINI, A. J.; BARRICHELO, L. E. G.; BRITO, O. J.; SILVA, M. G. da. Avaliação do potencial de algumas espécies de Eucalyptus. Piracicaba: IPEF, 1980. 5 p. (Circular Técnica).

NEVES, E. J. M; REISSMANN, C. B.; DÜNISCH, O. Biomassa e conteúdo de elementos minerais nos compartimentos arbóreos de Ceiba pentandra (L.) Gaertn. Boletim de Pesquisa Florestal, Colombo, v. 42, p. 47 - 56, 2001.

PÉREZ, S.; RENEDO, C. J.; ORTIZ, A.; DELGADO, F.; FERNÁNDEZ, I. Energy potential of native shrub species in northern Spain. Renewable Energy, Philadelphia, v. 62, p. 79 - 83, 2014.

SANTOS JR., U. M. dos; GONÇALVES, J. F. de C.; FELDPAUSCH, T. R. Growth, leaf nutrient concentration and photosynthetic nutrient use efficiency in tropical tree species planted in degraded areas in central Amazonia. Forest Ecology and Management, Amsterdam, v. 226, p. 299 - 309, 2006.

SANTOS, L. C.; CARVALHO, A. M. M. L.; PEREIRA, B. L. C.; OLIVEIRA, A. C.; CARNEIRO, A. de C.; TRUGILHO, P. F. Propriedades da madeira e estimativa de massa, carbono e energia de clones de Eucalyptus plantados em diferentes locais. Árvore, Viçosa, v. 36, p. 971 - 980, 2012.

SANTOS, E. C. S dos S.; SOUZA, R. C. R.; BARBOSA, K. H. N.; VASCONCELOS, M. A. de. Caracterização energética de espécies lenhosas nativas da Amazônia. Disponível em: <http://cdeam.ufam.edu.br/article/114/resumo_pioneiras.pdf>. Acesso em: 01/12/2013.

SILVA, H. D.; FERREIRA, C. A.; CORRÊA, R. S.; BELLOTE, A. F. J.; TUSSOLINI, E. L. Alocação de biomassa e ajuste de equações para estimativa de biomassa em compartimentos aéreos de Eucalyptus benthamii. Boletim de Pesquisa Florestal, Colombo, v. 49, p. 83 - 95, 2004.

SIREGAR, S. T. H.; NURWAHYUDI, M.; MULAWARMAN, K. Effects of inter-rotation management on site productivity of Acacia mangium in Riau Province, Sumatra, Indonesia. In: NAMBIAR, E.K.S. Site management and productivity in tropical plantation forests. Bogor: CIFOR, 2008. 236 p.

SOUZA, C. R.; LIMA, R. M. B de; AZEVEDO, C. P. de; ROSSI, L. M. B. Desempenho de espécies florestais para uso múltiplo na Amazônia. Scientia Forestalis, Piracicaba, v. 36, n. 77, p. 7 - 14, 2008.

TÉO, S. J. Quantificação e modelagem do conteúdo de nutrientes na biomassa aérea de bracatinga (Mimosa scabrella Bentham). 157 f. Dissertação (Mestrado em Engenharia Florestal, com opção em Manejo Florestal) - Universidade Federal do Paraná, Curitiba, 2009.

VIDAURRE, G. B.; CARNEIRO, A. de C. O.; VITAL, B. R.; SANTOS, R. C. dos; VALLE, M. L. A. Propriedades energéticas da madeira e do carvão de paricá (Shizolobium amazonicum). Árvore, Viçosa, v. 36, p. 3656 - 3671, 2012. 